\title{
Can herb-clover mixes increase lamb liveweight gains in spring?
}

\author{
S.C.S. SINHADIPATHIGE, P.R. KENYON, P.D. KEMP, S.T. MORRIS and P.C.H. MOREL \\ Sheep Research Centre, Institute of Veterinary, Animal and Biomedical Sciences, Massey University, Private \\ Bag 11-222, Palmerston North 4442, New Zealand \\ s.c.s.sinhadipathige@massey.ac.nz
}

\begin{abstract}
Herb-clover mixes have resulted in faster lamb liveweight gain than perennial ryegrass over summer, but it is not known if this would occur in spring. Lamb liveweight gain in spring was compared on three treatments: Pasture mix: perennial ryegrass and white clover; Plantain mix: plantain, white clover and red clover; and Chicory mix: plantain, chicory, white clover and red clover, over a 28-day period. Average daily liveweight gain $(\mathrm{g} /$ day $)$ was higher $(\mathrm{P}<0.05)$ on the Chicory mix $(360 \pm 20.0)$ than the Pasture mix $(322$ $\pm 10.0)$. Individual carcass weight was higher $(\mathrm{P}<0.05)$ on the Plantain and Chicory mixes than on the Pasture mix. Plantain mix produced $162 \mathrm{~kg}$ net carcass weight per ha compared to the Pasture mix (141 kg/ha) and Chicory mix (146 kg/ha). Farmers can obtain greater individual carcass weights and net carcass weight per ha by feeding herb-clover mixes rather than ryegrass pasture during the spring.
\end{abstract}

Keywords: herb-clover mixes, lamb growth, carcass weight

\section{Introduction}

Livestock production systems in New Zealand have become more specialised, signifying the necessity to complement the traditional ryegrass/white clover with alternative high nutritive value forages (Hodgson et al. 2005). Recently many research programmes have been undertaken to evaluate combinations of herb mixes for higher animal production (Fraser \& Rowarth 1996; Fraser et al. 1999; Kemp et al. 2010; Golding et al. 2011; Kenyon et al. 2011). Kemp et al. (2010) stated that farmers could achieve "marketable target weight" lambs within a shorter time by feeding a herb and clover mix than a perennial ryegrass/white clover mix. Forage legume mixes are high in quality and can improve the performance of ruminants (Waghorn \& Clark 2004). A herb-clover mix that persists and is productive throughout the year would be a valuable component of a high producing livestock system (Kemp et al. 2010).

Lamb liveweight gain from perennial ryegrass, tall fescue, or chicory (Fraser et al. 1999) in summer, autumn and winter, and from ryegrass, plantain, chicory, white clover or lotus (Fraser \& Rowarth 1996) in summer-early autumn and from ryegrass and plantain (Moorhead et al. 2002) in summer have been studied. There is no published information to date on lamb liveweight gain from herb-clover mixes (plantain, chicory and clovers) during the spring. Herb-clover mixes have been shown to improve the performance of lactating ewes and their lambs in spring (Kenyon et al. 2011). It has also been shown that lamb growth rates in autumn are greater on herb-clover mixes than on ryegrass (Golding et al. 2011). Therefore, the aim of this study was to determine whether lamb liveweight gain and carcass weights would be increased in spring by feeding herb-clover mixes compared to ryegrasswhite clover pasture.

\section{Methods}

The experimental site was situated between $40^{\circ} 21^{\prime}$ $\mathrm{S}$ and $175^{\circ} 37^{\prime} \mathrm{E}$ on the Moginie Pasture and Crop Research Unit, Massey University, $5 \mathrm{~km}$ south- east of Palmerston North, New Zealand, at an altitude of 30 m. The soil type was a Tokomaru Silt Loam which is imperfectly to very poorly drained due to a fragipan (Cowie \& Rijkse 1977). The total rainfall during the study period was $37 \mathrm{~mm}$ with a mean soil temperature (10 cm depth) of $9.4^{\circ} \mathrm{C}$. The study was conducted with the approval of the Massey University Animal Ethics Committee.

One hundred and ninety-five Texel $\times$ Romney male lambs aged approximately 11 months $(41.3 \pm 0.16$ $\mathrm{kg}$ ) were selected on 7 September $2011\left(\mathrm{D}_{1}\right)$. Lambs were stratified by liveweight and allocated to one of three treatments to ensure there was no difference in liveweights at the start of the study. The three treatments were: Pasture mix: ryegrass (Lolium perenne 'One50') and white clover (Trifolium repens 'Bounty'), Plantain mix: plantain (Plantago lanceolata 'Ceres Tonic'), white clover and red clover (Trifolium pratense 'Sensation') and Chicory mix: plantain, chicory (Cichorium intybus 'Puna II'), white clover and red clover. There were three mobs of lambs per treatment. The total area was 6.75 ha with 2.25 ha per treatment and 0.75 ha per treatment plot.

The Pasture mix and Plantain mix each had 69 lambs (23 lambs in each mob) while the Chicory mix had 57 lambs (19 lambs in each mob). Different stocking rates were used in order to maintain predicted herbage 
masses in all three treatments (i.e., final average mass to be similar to starting average mass), and also assuming herbage growth met animal requirements. The studies of Li \& Kemp (2005), Powell et al. (2007) and Kemp et al. (2010) were used to predict herbage growth during the study period.

The ryegrass pasture was sown in autumn 2009, and both Plantain mix and Chicory mix were sown into existing two-year-old plantain 'Ceres Tonic' and power harrowed to remove approximately one-third of the existing plants. Sowing rates were as follows for each treatment. Pasture mix: ryegrass $20 \mathrm{~kg} / \mathrm{ha}$ and white clover $4 \mathrm{~kg} / \mathrm{ha}$. Plantain mix: plantain $6 \mathrm{~kg} / \mathrm{ha}$, white clover $4 \mathrm{~kg} / \mathrm{ha}$ and red clover $6 \mathrm{~kg} / \mathrm{ha}$. Chicory mix: plantain $6 \mathrm{~kg} / \mathrm{ha}$, chicory $6 \mathrm{~kg} / \mathrm{ha}$, white clover $4 \mathrm{~kg} / \mathrm{ha}$ and red clover $6 \mathrm{~kg} / \mathrm{ha}$.

\section{Animal Management}

Lambs were rotationally grazed providing $a d$ lib intake with a herbage allowance of three times their predicted intake of $1.5 \mathrm{~kg} \mathrm{DM} / \mathrm{ha} /$ day (Kerr 2000). To ensure $a d$ lib conditions, lambs were shifted into a new grazing area when post-grazing sward surface height reached $5 \mathrm{~cm}$ in the Pasture mix and $7 \mathrm{~cm}$ in the Plantain and Chicory mixes. The nine groups of lambs (three treatments by three mobs) rotationally grazed their allocated treatment plot twice during the study.

On $\mathrm{D}_{1}$ lambs were orally drenched with Ancare 'Matrix' triple combination drench (active ingredients abamectin, oxfendazole and levamisole; Merial Ancare, Manukau City, New Zealand). Lambs were weighed within an hour of removal from the herbage on $\mathrm{D}_{1}$ and $\mathrm{D}_{28}$. On $\mathrm{D}_{29}$ the lambs were slaughtered at Alliance Meat Works, (Dannevirke, New Zealand).

\section{Herbage measurements}

Pasture mix was grazed during the months of June and July 2011. It was allowed to re-grow for 3 weeks before the start of the experiment. Similarly, after the end of the experiment Pasture, Plantain and Chicory mixes were allowed to re-grow before taking samples for botanical composition. Therefore, 2 weeks prior to $\mathrm{D}_{1}$ and also 2 weeks after $\mathrm{D}_{28}$ herbage samples were collected to determine the botanical composition. Twelve herbage samples were taken from each treatment plot (108 in total). The 12 samples were then mixed thoroughly and a 30-g sub-sample was taken to determine the percentage of ryegrass, white clover, red clover, plantain, chicory, weeds and dead matter. After separation, each portion was dried in a draught oven for at least 24 hours at $70^{\circ} \mathrm{C}$ to determine the relative composition ( $\%$ dry matter basis).

Four pre-grazing quadrant cuts $\left(0.1 \mathrm{~m}^{2}\right)$ were taken at ground level in each treatment plot to determine the herbage mass each time the lambs were moved to a new grazing area. Four post-grazing herbage cuts were taken within 24 hours of the removal of lambs from each treatment plot to determine the apparent utilisation of herbage (Brown et al. 2005). The samples were washed and oven dried in a draught oven at $70^{\circ} \mathrm{C}$ for a minimum of 24 hours. These dry weights were used to calculate the herbage mass on a DM basis.

Once weekly, 50 sward surface height measurements per grazing area were recorded using an Automated Sward Stick (JENQUIP, Feilding, New Zealand) to determine the height of the most recent post-grazing area (post-grazing) and the next grazing area (pregrazing).

Two enclosed cages were placed in each replicate (treatment plot) of the three treatments during the

Table 1. The effect of herbage treatment (Pasture mix vs Plantain mix vs Chicory mix) on the pre- and post-grazing herbage mass (DM basis) and apparent DM removal (mean \pm s.e.).

\begin{tabular}{lccc}
\hline Treatment & Pre-grazing $(\mathrm{kg} / \mathrm{ha})$ & Post-grazing $(\mathrm{kg} / \mathrm{ha})$ & Apparent DM Removal $(\mathrm{kg} / \mathrm{ha})$ \\
\hline Pasture mix & $2521.4 \pm 114.54$ & $1590.2^{\mathrm{a}} \pm 70.32$ & $931.2^{\mathrm{b}} \pm 134.39$ \\
Plantain mix & $2876.6 \pm 102.45$ & $1331.1^{\mathrm{b}} \pm 62.90$ & $1545.5^{\mathrm{a}} \pm 120.20$ \\
Chicory mix & $2719.5 \pm 103.86$ & $1405.2^{\mathrm{ab}} \pm 63.77$ & $1314.3^{\mathrm{ab}} \pm 121.86$ \\
\hline
\end{tabular}

Differing superscripts within columns indicate means that are significantly different $(\mathrm{P}<0.05)$.

Table 2. The effect of herbage treatment (Pasture mix vs Plantain mix vs Chicory mix) on crude protein (CP), neutral detergent fibre (aNDF) and acid detergent fibre (ADF) (mean \pm s.e.).

\begin{tabular}{lccc}
\hline Treatment & \multicolumn{3}{c}{ Herbage quality } \\
\hline & CP $(\% D M)$ & aNDF $(\% D M)$ & ADF (\%DM) \\
\cline { 2 - 4 } Pasture mix & $22.8 \pm 1.58$ & $39.6^{\mathrm{a}} \pm 0.54$ & $20.1^{\mathrm{a}^{\mathrm{a}} \pm 0.99}$ \\
Plantain mix & $19.1 \pm 1.58$ & $26.3^{\mathrm{b}} \pm 0.54$ & $15.1^{\mathrm{b}} \pm 0.99$ \\
Chicory mix & $16.5 \pm 1.58$ & $24.7^{\mathrm{b}} \pm 0.54$ & $16.5^{\mathrm{ab}} \pm 0.99$ \\
\hline
\end{tabular}

Differing superscripts within columns indicate means that are significantly different $(P<0.05)$. 
grazing period. Plucked herbage samples were collected from the cages at the end of each grazing to determine the nutritional value of the herbage consumed by lambs. These samples were frozen at $-20^{\circ} \mathrm{C}$. The samples were then freeze-dried, ground to pass a $1 \mathrm{~mm}$ screen and analysed for in vitro organic matter digestibility according to the method of Roughan \& Holland (1977), crude protein (CP; by a Leco total combustion method), neutral detergent fibre (aNDF) and acid detergent fibre (ADF) in a Tecator Fibretec System (Robertson \& Van Soest 1981). Alpha amylase was added during extraction to determine aNDF.

\section{Statistical analysis}

Individual lamb and herbage data were analysed using a nested linear model with herbage treatment as a fixed effect and mob/replicate (treatment plot) nested within herbage treatment as a random effect using proc GLM in SAS version 9.2 (SAS 2008).

\section{Results}

\section{Herbage mass}

The pre-grazing herbage mass did not differ $(\mathrm{P}>0.05)$ between the herbage treatments (Table 1). Post-grazing herbage mass was greater $(\mathrm{P}<0.05)$ in the Pasture mix compared to the Plantain mix. However, apparent herbage DM removal was greater $(\mathrm{P}<0.05)$ in the Plantain mix compared to the Pasture mix. Post-grazing herbage mass and apparent herbage DM removal of the Chicory mix did not differ $(\mathrm{P}>0.05)$ from either of the other two treatments.

\section{Herbage composition}

In the Pasture mix, ryegrass was the dominant species, both at the start ( $73 \%$ ryegrass and $6 \%$ white clover) and the end ( $74 \%$ ryegrass and $4 \%$ white clover) of the study. Plantain was the dominant species in both Plantain and Chicory mixes comprising $42 \%$ and $38 \%$, respectively, at start of the study and $56 \%$ and $38 \%$, respectively, at the end. The proportion of chicory in the Chicory mix was $9 \%$ at start and $15 \%$ at the end of the study. The proportions of red clover and white clover in the Plantain mix were $3 \%$ and $4 \%$ at the beginning and $7 \%$ and $13 \%$ respectively at the end of the study. Similarly, in the Chicory mix the proportions of red clover and white clover were $4 \%$ and $4 \%$ at the beginning and $9 \%$ and $15 \%$ respectively at the end of the study.

\section{Herbage quality}

The Pasture mix had a higher $(\mathrm{P}<0.05)$ ADF concentration than the Plantain mix and a higher $(\mathrm{P}<0.05)$ aNDF concentration than both the Plantain and Chicory mixes. Crude protein concentration did not differ between the three treatments (Table 2).

\section{Sward height}

Pre-grazing sward heights did not differ $(\mathrm{P}>0.05)$ between herbage treatments. However, the Plantain mix had lower $(\mathrm{P}<0.05)$ post-grazing sward height than the Chicory mix (Table 3 ).

\section{Animal liveweight}

Herbage treatment had a significant effect on average daily liveweight gain of the lambs, with lambs on the

Table 3. The effect of herbage treatment (Pasture mix vs Plantain mix vs. Chicory mix) on pre- and post-grazing sward height measurements (mean \pm s.e.).

\begin{tabular}{lcc}
\hline Treatment & Pre-grazing sward height $(\mathrm{cm})$ & Post-grazing sward height $(\mathrm{cm})$ \\
\hline Pasture mix & $13.6 \pm 0.34$ & $7.3^{\mathrm{ab}} \pm 0.43$ \\
Plantain mix & $13.6 \pm 0.30$ & $6.1^{\mathrm{b}} \pm 0.38$ \\
Chicory mix & $14.3 \pm 0.30$ & $7.5^{\mathrm{a}} \pm 0.38$ \\
\hline
\end{tabular}

Differing superscripts within columns indicate means that are significantly different $(P<0.05)$.

Table 4 The effect of herbage treatment (Pasture mix vs. Plantain mix vs Chicory mix) on lamb liveweight, average daily gain (ADG), carcass weight per lamb (mean \pm s.e.) and net carcass weight per ha.

\begin{tabular}{|c|c|c|c|c|c|c|}
\hline \multirow[t]{2}{*}{ Treatment } & \multirow{2}{*}{$\begin{array}{l}\text { Stocking rate } \\
\text { lambs/ha }\end{array}$} & \multicolumn{2}{|c|}{ Liveweight (kg) } & \multirow{2}{*}{$\begin{array}{c}\operatorname{ADG}\left(D_{1}-D_{28}\right) \\
\text { (g/day) }\end{array}$} & \multirow{2}{*}{$\begin{array}{c}\text { Carcass } \\
\text { weight/lamb } \\
(\mathrm{kg} / \mathrm{lamb})\end{array}$} & \multirow{2}{*}{$\begin{array}{c}\text { Net carcass } \\
\text { weight/ha } \\
(\mathrm{kg} / \mathrm{ha})\end{array}$} \\
\hline & & Day1 & Day 28 & & & \\
\hline Pasture mix & 30 & $41.4 \pm 0.07$ & $50.4 \pm 0.35$ & $322^{\mathrm{b}} \pm 10.0$ & $21.2^{\mathrm{c}} \pm 0.11$ & 141 \\
\hline Plantain mix & 30 & $41.2 \pm 0.07$ & $50.6 \pm 0.35$ & $336^{\mathrm{ab}} \pm 10.0$ & $21.8^{\mathrm{b}} \pm 0.11$ & 162 \\
\hline Chicory mix & 25 & $41.3 \pm 0.08$ & $51.4 \pm 0.38$ & $360^{a} \pm 20.0$ & $22.3^{\mathrm{a}} \pm 0.12$ & 146 \\
\hline
\end{tabular}

tADG was calculated as follows: (D28-D1/ 28 days) ${ }^{*} 1000$

Differing superscripts within columns indicate means that are significantly different $(P<0.05)$. 
Chicory mix gaining more $(\mathrm{P}<0.05)$ than those on the Pasture mix (Table 4). Average daily liveweight gain on the Pasture mix and the Plantain mix were similar. There was no difference $(\mathrm{P}>0.05)$ in liveweight at $\mathrm{D}_{1}$ or $\mathrm{D}_{28}$ between herbage treatments (Table 4 ). Chicory mix lambs had a higher $(\mathrm{P}<0.05)$ carcass weight per lamb than the Plantain mix or the Pasture mix lambs, and Plantain mix lambs had a higher $(\mathrm{P}<0.05)$ carcass weight than Pasture mix lambs. However, net carcass weight per ha was marginally higher on the Plantain mix than on the Pasture and Chicory mixes, although this could not be statistically tested.

\section{Discussion}

The aim of this study was to determine whether feeding herb-clover mixes (plantain, chicory and clover mixes) in the spring would improve lamb liveweight gain and carcass weight compared to ryegrass and white clover pasture mix. The daily liveweight gains of lambs on the Pasture, Plantain and Chicory mixes were greater than $300 \mathrm{~g} /$ day, which demonstrated that the feeding value of all three forage mixes was very high in spring. The results show that the Chicory mix resulted greater liveweight gains and Chicory and Plantain mixes resulted greater carcass weights than that of the Pasture mix during spring. Golding et al. (2011) showed that lamb liveweight gains were superior in late summer and autumn. This study and that of Golding et al. (2011) both suggest that lamb finishing systems that use herbclover mixes out-perform those that use ryegrass and white clover pasture over summer and autumn, without any compromise in spring performance.

However, the Chicory mix had a lower stocking rate (25 lambs/ha) compared to the Pasture and Plantain mixes (30 lambs/ha). A lower stocking rate was selected for the Chicory mix due to its projected lower herbage growth rate in winter and early spring ( $\mathrm{Li} \&$ Kemp 2005). The herbage sward masses and sward height measurements in all three treatments indicated herbage intake was not restricted (Kerr 2000; Webby \& Pengelly 1986), suggesting that the lower stocking rate in Chicory for spring was appropriate.

The high feeding value (Waghorn \& Clark 2004) of all three forage mixes in spring demonstrated by the high liveweight gains was reflected in the nutritive value. The higher fibre (ADF and aNDF) and higher protein $(\mathrm{CP})$ in the Pasture mix relative to the two herb-based mixes, while not as great as that observed by Golding et al. (2011) in autumn, showed the same trend. An advantage of the herb-based mixes is their lower fibre content enabling higher daily intakes (Kerr 2000). The lower crude protein content of the Plantain and Chicory mixes are in the acceptable range of 15$18 \%$ for finishing lambs (Hodgson \& Brookes 1999;
Waghorn \& Clark 2004) and, whilst not a limitation to lamb growth in this study, does support the importance of including legumes in herb-based pastures.

\section{ACKNOWLEDGEMENT}

Mark Osborne, Simon Orsborn, Dean Burnham, Geoff Purchas have provided the technical assistance with pasture and animal measurements. International Sheep Research Centre, Massey University and the National Research Centre for Growth and Development funded this research.

\section{References}

Brown, H.E.; Moot, D.J.; Pollock, K.M. 2005. Herbage production, persistence, nutritive characteristics and water use of perennial forages grown over 6 years on a Wakanui silt loam. New Zealand Journal of Agricultural Research 48: 423-439.

Cowie, J.D.; Rijkse, W.C. 1977. Soils of Manawatu County, North Island, New Zealand. New Zealand Soil Survey Report 30, New Zealand Soil Bureau, Department of Scientific and Industrial Research, Wellington, New Zealand.

Fraser, T.J.; Moss, R.A.; Daly, M.J.; Knight, T.L. 1999. The effect of pasture species on lamb performance in dryland systems. Proceedings of New Zealand Grassland Association 61: 23-29.

Fraser, T.S.; Rowarth, J.S. 1996. Legumes, herbs or grass for lamb growth. Proceedings of the New Zealand Grassland Association 58: 49-52.

Golding, K.P.; Wilson, E.D.; Kemp, P.D.; Pain, S.J.; Kenyon, P.R.; Morris, S.T.; Hutton, P.G. 2011. Mixed herb and legume pasture improves the growth of lambs post-weaning. Animal Production Science 51: 717-723.

Hodgson, J.; Brookes, I.M. 1999. Nutrition of grazing animals. pp. 117-132. In: New Zealand pastures and crop sciences. Eds. White, J.; Hodgson, J. Oxford University Press, Australia and New Zealand.

Hodgson, J.; Cameron, K.; Clark, D.; Condron, L.; Fraser, T.; Hedley, M.; Holmes, C.; Kemp, P.; Lucas, R.; Moot, D.; Morris, S.; Nicholas, P.; Shadbolt, N.; Sheath, G.; Valentine, I.; Waghorn, G.D.W. 2005. New Zealand's pastoral industries: efficient use of grassland resources. pp. 181-205. In: Grasslands: developments, opportunities, perspectives. Eds. Reynolds, S.A.; Frame, J. Science Publishers, Inc., Enfield (NH), USA.

Kemp, P.D.; Kenyon, P.R.; Morris, S.T. 2010. The use of legume and herb forage species to create high performance pastures for sheep and cattle grazing systems. Sociedade Brasileira de Zootecnia 39: 169174. 
Kenyon, P.R.; Kemp, P.D.; Stafford, K.J.; West, D.M.; Morris, S.T. 2011. Can a herb and white clover mix improve the performance of multiple-bearing ewes and their lambs to weaning? Animal Production Science 50: 513-521.

Kerr, P. 2000. 400 plus - a guide to improved lamb growth. New Zealand Sheep Council, Wellington.

Li, G.; Kemp, P.D. 2005. Forage chicory (Cichorium intybus L.): A review of its agronomy and animal production. Advances in Agronomy 88: 187-222.

Moorhead, A.J.E.; Judson, H.G.; Steward, A.V. 2002. Live weight gain of lambs grazing 'Ceres Tonic' plantain (Plantago lanceolata) or perennial ryegrass (Lolium perenne). Proceedings of the New Zealand Society of Animal Production 62: 171-173.

Powell, A.M.; Kemp, P.D.; Jaya, I.K.D.; Osborne, M.A. 2007. Establishment, growth and development of plantain and chicory under grazing. Proceedings of the New Zealand Grassland Association 69: 41-45.
Robertson, J.; Van Soest, P. 1981. The detergent system of analysis and its application to human foods. pp. 123-158. In: The Analysis of Dietary Fiber in Food Volume 3. Eds. James, W.P.T.; Theander, O. Marcel Dekker Inc., New York, USA.

Roughan, P.G.; Holland, R. 1977. Predicting in-vivo digestibility of herbages by exhaustive enzymic hydrolysis of cell walls. Journal of the Science of Food and Agriculture 28: 1057-1064.

SAS 2008. SAS 9.2. SAS Institute Inc., Cary, NC.

Waghorn, G.C.; Clark, D.A. 2004. Feeding value of pastures for ruminants. New Zealand Veterinary Journal 52: 320-331.

Webby, R.W.; Pengelly, W.J. 1986. The use of pasture height as a predictor of feed level in North Island Hill Country. Proceedings of New Zealand Grassland Association 47: 249-253. 
